\title{
Effects of Salts on the Conformation and Catalytic Properties of D-Amino Acid Aminotransferase
}

\author{
Hyeon-Su Ro* \\ Biomolecular Process Engineering Laboratory, Korea Research Institute of Bioscience and Biotechnology, Daejeon, Korea
}

Received 29 December 2001, Accepted 27 February 2002

\begin{abstract}
The effects of salts on the biochemical properties of $D$ amino acid aminotransferase from Bacillus sp. YM-1 have been studied to elucidate both the inhibitory effects of salts on the activity and the protective effects of salts on the substrate-induced inactivation. The results from UVvisible spectroscopy studies on the reaction of the enzyme with $D$-serine revealed that salt significantly reduced the rate of the formation of the quinonoid intermediate and its accumulation. The kinetic and spectroscopy studies of the reaction with $\alpha-\left[{ }^{2} \mathrm{H}\right]-\mathrm{DL}$-serine in different concentrations of $\mathrm{NaCl}$ provided evidence that the rate-limiting step was changed from the deprotonation of the external aldimine to another step(s), presumably to the hydrolysis of the ketimine. Gel filtration chromatography data in the presence of $\mathrm{NaCl}$ showed that the enzyme volume was reduced sharply with the increasing $\mathrm{NaCl}$ concentration, up to $100 \mathrm{mM}$. An additional increase of the $\mathrm{NaCl}$ concentration did not affect the elution volume, which suggests that the enzyme has a limited number of saltbinding groups. These results provide detailed mechanistic evidence for the way salts inhibit the catalytic activity of Damino acid aminotransferase.
\end{abstract}

Keywords: Aminotransferase, Quinonoid, Conformation, Gel filtration

\section{Introduction}

The transamination reaction that is catalyzed by D-amino acid aminotransferase (D-AAT) provides bacterial cells with Damino acids, which are important constituents for the cell wall and secondary metabolites (Martinez-Carrion and Jenkins, 1965a, b; Yonaha et al., 1975; Fotheringham et al., 1998). Some bacterial cells use other enzyme systems, like alanine racemase (Kim and Yu, 2000), glutamate racemase, etc. D-

*To whom correspondence should be addressed.

Tel: 82-42-860-4443; Fax: 82-42-860-4594

E-mail: rohyeon@mail.kribb.re.kr
AAT requires the cofactor pyridoxal 5'-phosphate (PLP), which is bound to the enzyme through a Schiff base that is formed between PLP and the lysine residue of the active site (Yonaha et al., 1975; Tanizawa et al., 1989) (E-PLP in Fig. 1). In the absence of a substrate, E-PLP is in equilibrium with Ealdamine, which has a saturated C4' with an unknown functional group (Ro et al., 1996). In the presence of a Damino acid, the $\alpha$-amino group of the substrate replaces the active site lysine residue in order to form the Schiff base between the substrate and PLP (E-PLP-D-AA) (MartinezCarrion and Jenkins, 1965a). In the first half reaction, E-PLP$\mathrm{D}-\mathrm{AA}$ is converted to a quinonoid intermediate (E-Q) by deprotonation at the $\alpha$-carbon of D-amino acid, then E-Q is subsequently converted to the enzyme complex with pyridoxamine phosphate and $\alpha$-keto acid $(\mathrm{E}-\mathrm{PMP}+\alpha-\mathrm{KA})$ via E-ketimine and E-carbinolamine (Martinez-Carrion and Jenkins, 1965a; Martinez del Pozo et al., 1989). The secondhalf reaction is the reverse of the first-half reaction, except that a new $\alpha$-keto acid reacts with E-PMP to form a new D-amino acid.

DAAT is reported to be inactivated by D-alanine, which is a normal substrate for the enzyme, in the absence of a $\alpha$-keto acid (Martinez del Pozo et al., 1992; Bhatia et al., 1993; van Opem et al., 1998). This inactivation is due to the formation of the PLP-related adduct (PXP) through the $\alpha$ decarboxylation of E-Q during the normal catalysis with Dalanine in the absence of a $\alpha$-keto acid (van Opem et al., 1998). Formation of PXP is proportional to the formation of E-Q, which has a characteristic absorption peak at $493 \mathrm{~nm}$ (Martinez del Pozo et al., 1989). A recent report demonstrated that the inactivation could be protected by various salts (van Opem et al., 1998). The report suggested that salts might impede the release of pyruvate, which was suggested as a main cause of inactivation from the active site to enter the second-half reaction, thereby decreasing the overall turnover. Therefore, the protection effect of salts from the D-alanineinduced inactivation was interpreted as being due to the reduced release of free pyruvate. The reaction of the enzyme with its quasisubstrate D-serine mainly accumulates E-Q 


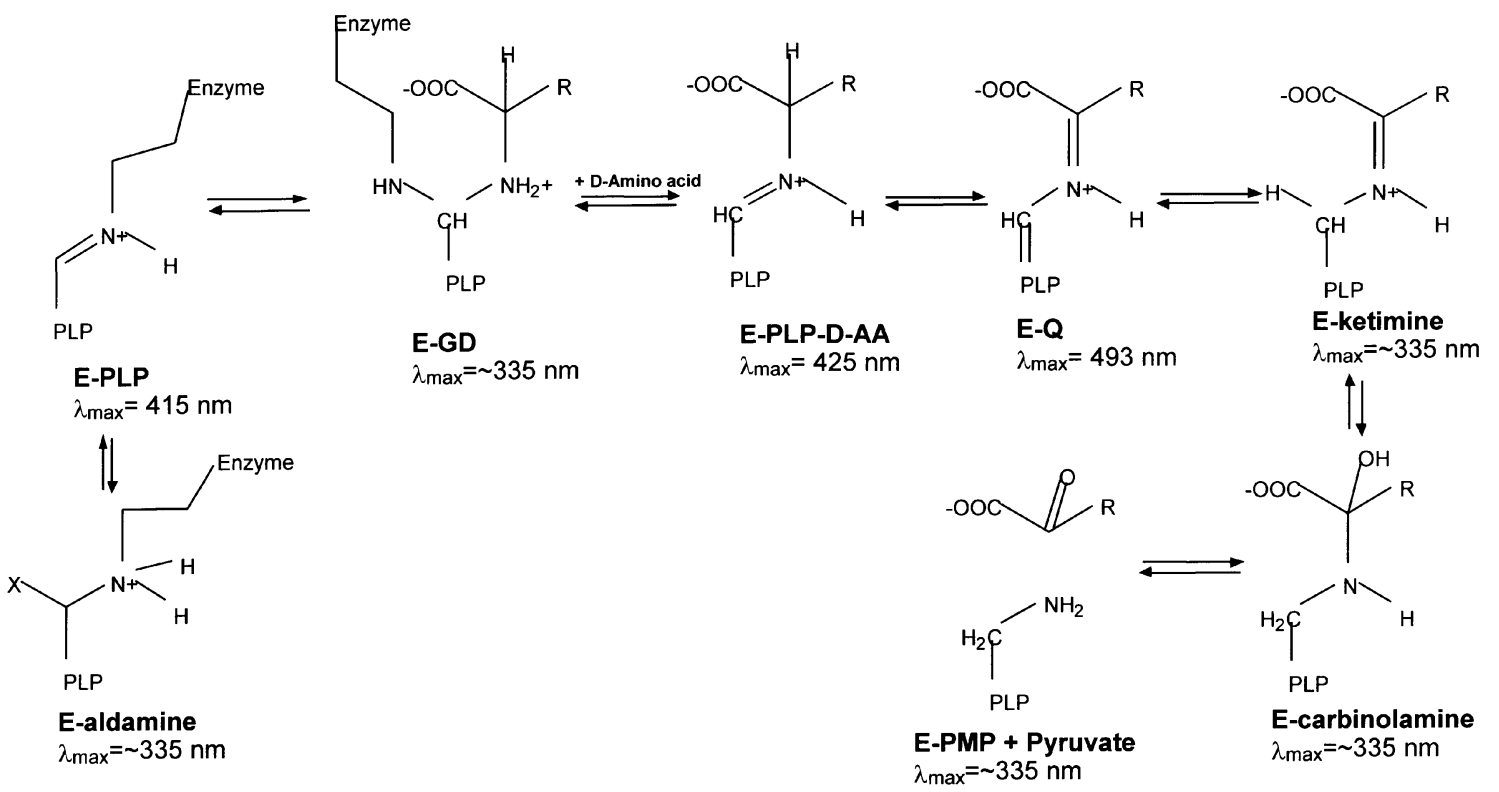

Fig. 1. Reaction mechanism of D-amino acid aminotransferase (E) with D-amino acid (D-AA).

(Martinez del Pozo et al., 1989). The activity of the enzyme toward D-serine is no more than $2 \%$ of the activity with Dalanine (Martinez del Pozo et al., 1989; Tanizawa et al., 1989). Therefore, D-serine is a useful substrate for the investigation of the inactivation phenomena, because it provides much more E-Q where the inactivation pathway starts and produces less pyruvate to slow down the inactivation process.

Salts are known to affect the enzyme conformation. Low and Somero (1975a, b) showed that salts affect the protein volume and decrease the activity of some enzymes. They also suggested that salts disrupt the dense hydration spheres around the exposed protein groups, which affects the enzyme volume. In this regard, the salt-induced inhibition and inactivation of D-AAT may be related to the salt-induced enzyme volume change. This report demonstrates that $\mathrm{NaCl}$ significantly reduces the enzyme volume. This leads to a change in the rate-limiting step of the catalytic reaction from the deprotonation of substrate to other steps.

\section{Materials and Methods}

Bacterial strain, enzyme purification, and assay The D-AAT from Bacillus sp. YM-1 was expressed in Escherichia coli JM105, as described previously (Ro et al., 1996). The cells were suspended in $30 \mathrm{mM}$ Tris- $\mathrm{HCl}(\mathrm{pH} \quad 7.3)$ that contained $0.01 \% \quad \beta$ mercaptoethanol and $20 \mu \mathrm{M}$ PLP, then broken by sonication. The crude cell extract was incubated at $65^{\circ} \mathrm{C}$ for $10 \mathrm{~min}$. The pellet was then removed by centrifugation at $15000 \mathrm{rpm}$ for $30 \mathrm{~min}$. The supernatant was applied to a Pharmacia Resource Q anion exchange column (Uppsala, Sweden), then eluted with a linear gradient of $\mathrm{NaCl}$ from 0 to $1 \mathrm{M}$. The enzyme activity was measured in the presence of $100 \mathrm{mM}$ D-alanine, $20 \mathrm{mM} \alpha$-ketoglutarate, and $50 \mu \mathrm{M}$ pyridoxal $5^{\prime}$-phosphate at $50^{\circ} \mathrm{C}$ by a spectrophotometric assay that was coupled with lactic dehydrogenase (Miles and Mcphie, 1974). A triethanolamine buffer (50 mM, pH 8.5) was used to maintain $\mathrm{pH}$ of the reaction mixture since Tris or other saltbased buffers were found to inhibit the enzyme activity (see the Results Section). One unit of activity is defined as the amount of the enzyme (mg) that forms 1 mmole of pyruvate in $1 \mathrm{~min}$ at $50^{\circ} \mathrm{C}$.

Spectroscopic methods Absorption spectra were measured using a Hewlett Packard 8452 diode array spectrophotometer. The reaction mixture contained the enzyme $(1 \mathrm{mg} / \mathrm{ml})$, triethanolamine buffer $(50 \mathrm{mM}, \mathrm{pH} 8.5)$, D-alanine or D-serine $(100 \mathrm{mM})$, and various concentrations of $\mathrm{NaCl}$. Fluorescence spectra were made using a PTI spectrofluorometer (Photon Technology International). The measurement conditions were the same as for the absorption spectra, except the enzyme concentration was $0.5 \mathrm{mg} / \mathrm{ml}$. All spectra were obtained at $25^{\circ} \mathrm{C}$.

Gel filtration chromatography Gel filtration chromatography was carried out at $4^{\circ} \mathrm{C}$ on a FPLC system using a Superose 12HR $10 / 30$ column $(1 \times 30 \mathrm{~cm})$ at a flow rate of $0.4 \mathrm{ml} / \mathrm{min}$. The enzyme ( $1 \mathrm{mg}$ in $100 \mu \mathrm{l}$ of elution buffer) was injected and eluted with a 50 $\mathrm{mM}$ triethanolamine buffer $(\mathrm{pH}$ 8.3) in the absence and presence of D-alanine $(0.1 \mathrm{M})$ with various concentrations of $\mathrm{NaCl}(0-5 \mathrm{M})$.

Preparation of $\boldsymbol{\alpha}-\left[{ }^{2} \mathbf{H}\right]$-DL-serine The $\alpha-\left[{ }^{2} \mathrm{H}\right]-\mathrm{DL}-\mathrm{Serine}$ was prepared as reported (Miles and Mcphie, 1974). The pyridoxal free base was prepared by loading $1 \mathrm{~g}$ pyridoxal hydrochloride onto a column of Dowex 50-H+ and elution with $2 \mathrm{M}$ ammonium hydroxide. The fractions that contained pyridoxal free base were freeze-dried. DL-serine $(5 \mathrm{~g})$ and pyridoxal were dissolved in $100 \mathrm{ml}$ of $\mathrm{D}_{2} \mathrm{O}$, and the $\mathrm{pD}$ was adjusted to 9.6 with $5 \mathrm{M}$ KOD. The solution was freeze-dried, dissolved in $100 \mathrm{ml}$ of $\mathrm{D}_{2} \mathrm{O}$, and combined with $\mathrm{Al}_{2}\left(\mathrm{SO}_{4}\right)_{3} \cdot 18 \mathrm{H}_{2} \mathrm{O}(1 \mathrm{~g})$ that had been previously freeze-dried from $5 \mathrm{ml}$ of $\mathrm{D}_{2} \mathrm{O}$. The solution was incubated for 2 days at room temperature in the dark. The reaction mixture was 


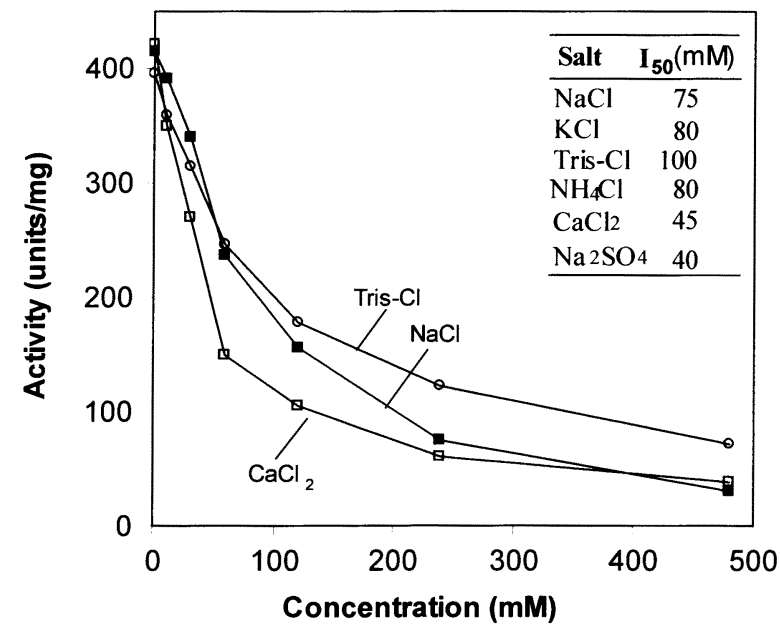

Fig. 2. Inhibition of the enzyme activity in the transamination reaction by various salts. $I_{50}$ is a concentration of salt $(\mathrm{mM})$ that inhibits $50 \%$ of the enzyme activity.

precipitated with acetone, washed with 50\% ethanol twice, dissolved in water, treated with activated charcoal, and recrystallized. The final yield was 70\% (3.5 $\mathrm{g} \alpha-\left[{ }^{2} \mathrm{H}\right]$-DL-serine).

\section{Results}

Effect of salts on the activity In order to determine the effect of salts on the activity of D-AAT, the transamination activity of the enzyme in the presence of various salts $(\mathrm{NaCl}$, $\mathrm{KCl}, \mathrm{NH}_{4} \mathrm{Cl}, \mathrm{CaCl}_{2}, \quad\left(\mathrm{NH}_{4}\right)_{2} \mathrm{SO}_{4}, \mathrm{Na}_{2} \mathrm{SO}_{4}$, Tris-Cl $)$ was examined. The activity was measured in the presence of 100 $\mathrm{mM}$ D-alanine, $20 \mathrm{mM} \quad \alpha$-ketoglutarate with different concentrations of salts at $50^{\circ} \mathrm{C}$ (Fig. 2). A triethanolamine buffer $(50 \mathrm{mM})$ was used in order to avoid the inhibitory effect of Tris- $\mathrm{Cl}$ or other salt-based buffers. The specific activity was 450 units/mg in the absence of salt, but decreased with increasing salt concentration. Only $40 \%$ of the activity was expressed at $0.1 \mathrm{M} \mathrm{NaCl}$ or $\mathrm{KCl}$, which is a conventional concentration that is used for enzyme studies. With $\mathrm{CaCl}_{2}$, the inhibition was much more significant than $\mathrm{NaCl}$. Forty-five $\mathrm{mM}$ of $\mathrm{CaCl}_{2}$ was enough to inhibit $50 \%$ of the enzyme activity. Interestingly, the Tris-Cl buffer also showed a similar inhibition curve to the other salts. All of the salts that were tested were inhibitory (see the Table in the inset of Fig. 2).

Effects of salts on the absorption spectra The absorption spectrum of D-AAT in the presence of D-alanine is shown in Fig. 3A. The reaction of D-alanine with D-AAT showed a strong absorption band at $335 \mathrm{~nm}$, which is attributed to EPMP, E-ketimine, and E-carbinolamine (Martinez-Carrion et al., 1965; Martinez del Pozo et al., 1989). The weak absorption band at $420 \mathrm{~nm}$ is attributed to the external aldimine form of the enzyme (E-PLP-D-ala). The addition of $500 \mathrm{mM} \mathrm{NaCl}$ did not change the distribution of the enzymesubstrate intermediates. The reaction of D-AAT with its
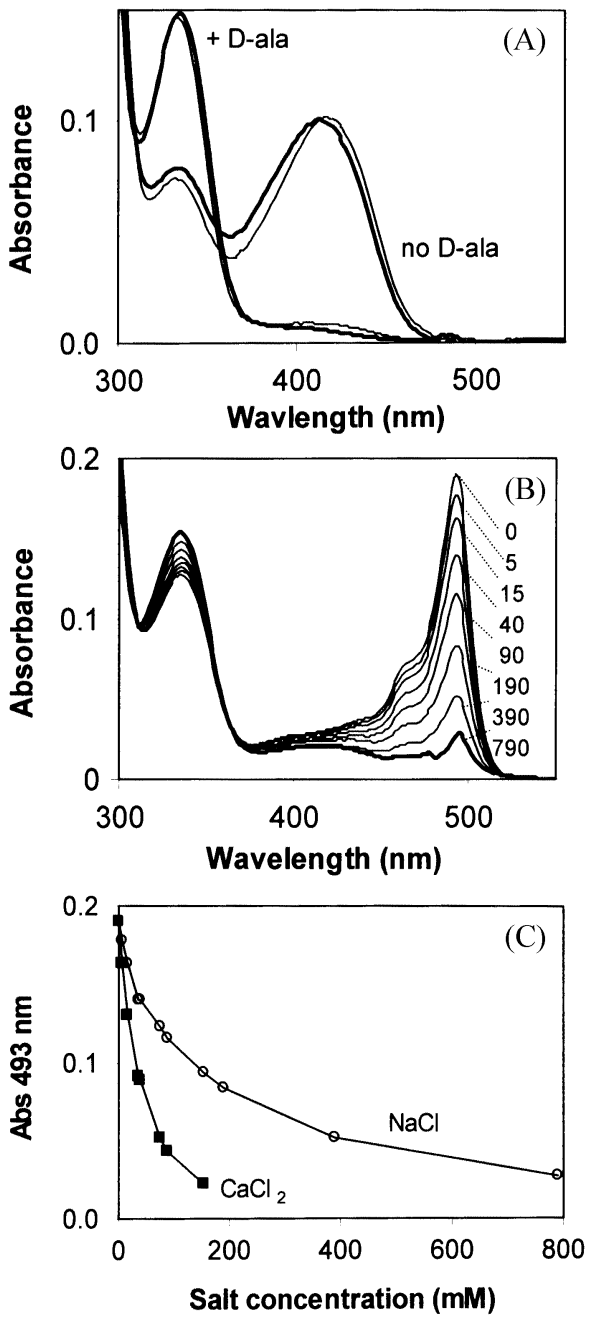

Fig. 3. Effects of salts on the UV/Vis spectral properties. (A) UV/Vis spectrum with or without the substrate $(0.1 \mathrm{M} \mathrm{D}$ alanine). The spectra were unaffected by $\mathrm{NaCl}$ (thin line: without $\mathrm{NaCl}$, thick line: $0.5 \mathrm{M} \mathrm{NaCl}$ ). (B) Effect of $\mathrm{NaCl}$ concentration on UV/Vis spectrum from the reaction of the enzyme with 100 $\mathrm{mM}$ D-serine. The spectrum was taken 2 min after mixing. The numbers shown on the right side of the figure indicate the concentration of $\mathrm{NaCl}(\mathrm{mM})$. (C) Effect of salts on the accumulation of E-Q.

quasisubstrate D-serine produced an intense absorption peak at $493 \mathrm{~nm}$, which is attributed to a quinonoid intermediate (EQ) (Martinez-Carrion et al., 1965; Martinez del Pozo et al., 1989). The intensity of the $493 \mathrm{~nm}$ band decreased with the increasing $\mathrm{NaCl}$ concentration with a concomitant increase of the $335 \mathrm{~nm}$ band (Fig. 3B). Therefore, $\mathrm{NaCl}$ may shift the equilibrium between E-Q, and the E-PMP forms towards the latter forms. Half of the absorbance at $493 \mathrm{~nm}$ diminished with $100 \mathrm{mM} \mathrm{NaCl}$ or $50 \mathrm{mM}$ of $\mathrm{CaCl}_{2}$.

Effects of $\mathrm{NaCl}$ on the rate of formation of $\mathrm{E}-\mathrm{Q}$ The initial rate of the formation of the $493 \mathrm{~nm}$ absorption peak was examined in the presence of $100 \mathrm{mM}$ D-serine at various 

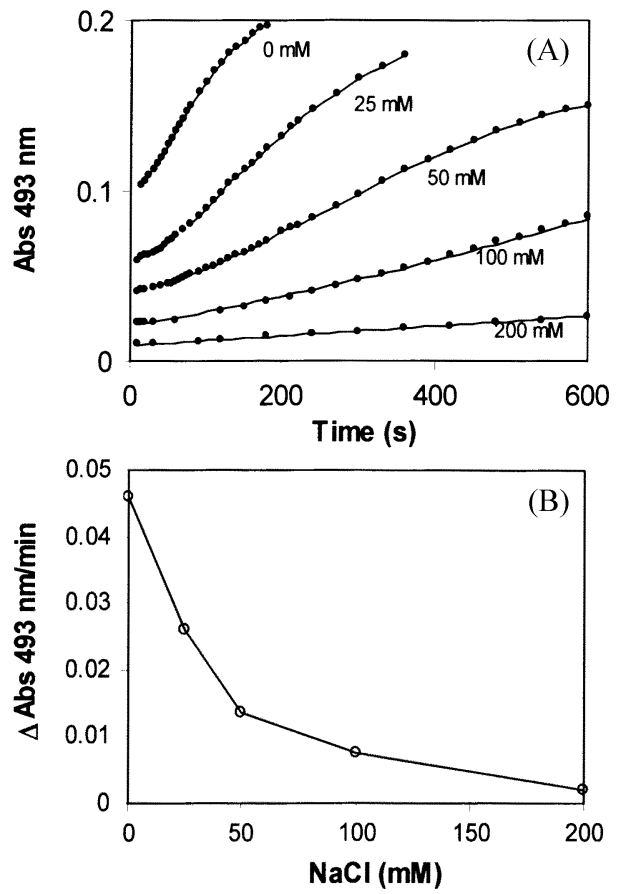

Fig. 4. Effects of $\mathrm{NaCl}$ concentration on the rate of the formation of E-Q (493 nm peak) from the reaction of the enzyme with $100 \mathrm{mM}$ D-serine. (A) Time-course of the $493 \mathrm{~nm}$ peak at different concentrations of $\mathrm{NaCl}$. (B) Effect of $\mathrm{NaCl}$ on the rate of the formation of E-Q. The first-order rate constant was calculated from the linearly increasing region of the data in (A).

concentrations of $\mathrm{NaCl}$ (Fig. 4). The rate decreased sharply up to $100 \mathrm{mM} \mathrm{NaCl}$, then showed a slow decrease at higher $\mathrm{NaCl}$ concentrations. Since the reaction of D-AAT with D-serine establishes the equilibrium between E-Q and one of the enzyme-substrate intermediates, which absorb at $335 \mathrm{~nm}$, the time-dependent increase of the $493 \mathrm{~nm}$ peak (Fig. 4) may not reflect the deprotonation rate at the $\alpha$-carbon of external aldimine (E-PLP-D-ser) to form E-Q. Rather, it reflects a slow conversion of the $335 \mathrm{~nm}$ species to E-Q, which eventually goes into the inactivation pathway through the decarboxylation from the a-carbon of E-Q.

Effect of $\mathrm{NaCl}$ on the reaction of D-AAT with $\alpha-\left[{ }^{2} \mathrm{H}\right]-\mathrm{DL}$ serine The value of the kinetic isotope effect 2-3 was reported from the reaction of D-AAT from Bacillus sphaericus with DL-alanine in a $0.3 \mathrm{M}$ potassium phosphate buffer (Soper and Manning, 1981). This indicates that the $\alpha$ deprotonation step is partially rate-limiting. Assuming that this is true for D-AAT from the Bacillus YM-1, the addition of $\alpha-\left[{ }^{2} \mathrm{H}\right]$-DL-serine would limit the rate at this step. Fig. 5A shows the spectra of D-AAT with $\alpha-\left[{ }^{2} \mathrm{H}\right]-\mathrm{DL}$-serine in the absence and presence of $100 \mathrm{mM} \mathrm{NaCl}$. As expected, the EPLP-D-ser (425 nm) became one of the major peaks and E-Q peak increased in a time-dependent manner, which indicates that $\alpha$-deprotonation occurs at a slow rate (Fig. 5B). The effect of $\mathrm{NaCl}$ on the rate of the formation of E-Q (calculated
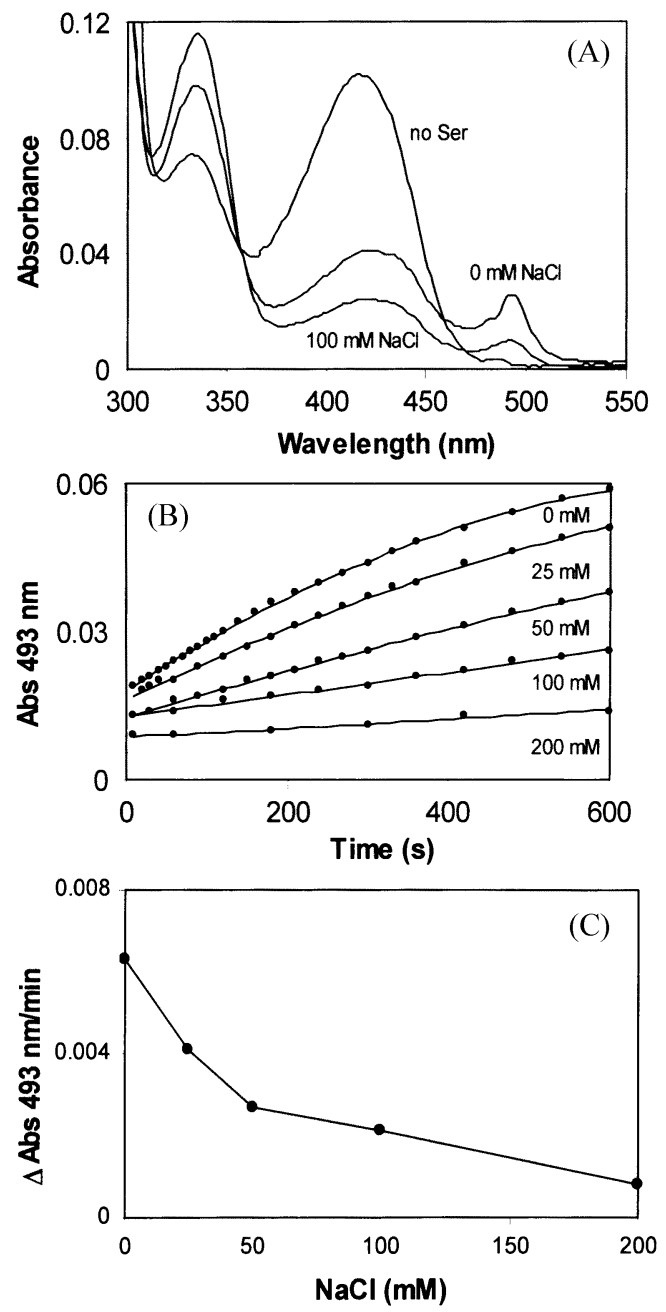

Fig. 5. The reaction of D-AAT with $\alpha-\left[{ }^{2} \mathrm{H}\right]-\mathrm{DL}-$ serine. (A) UV/ Vis spectrum with or without substrate $\left(200 \mathrm{mM} \alpha-\left[{ }^{2} \mathrm{H}\right]-\mathrm{DL}-\right.$ serine) at different $\mathrm{NaCl}$ concentrations. (B) Time-course of the $493 \mathrm{~nm}$ peak at different concentrations of $\mathrm{NaCl}$. (C) Effect of $\mathrm{NaCl}$ on the rate of the formation of E-Q.

from Fig. 5B) is shown in Fig. 5C. The data indicate that salt does inhibit the a-deprotonation step.

Gel filtration chromatography Gel filtration chromatography was carried out to elucidate the effect of $\mathrm{NaCl}$ on the enzyme conformation. As shown in Fig. 6, the elution volume of the enzyme was highly dependent on the salt concentration. The elution volume increased sharply, up to $100 \mathrm{mM} \mathrm{NaCl}$ (indicating a salt-dependent reduction of the enzyme volume), and showed a slow increase at a higher concentration. Further increase of the $\mathrm{NaCl}$ concentration from $0.5 \mathrm{M}$ to $5 \mathrm{M}$ showed little effect. The addition of a substrate did not affect the elution volume.

\section{Discussion}

Salts inhibit the enzyme activity Many studies have 

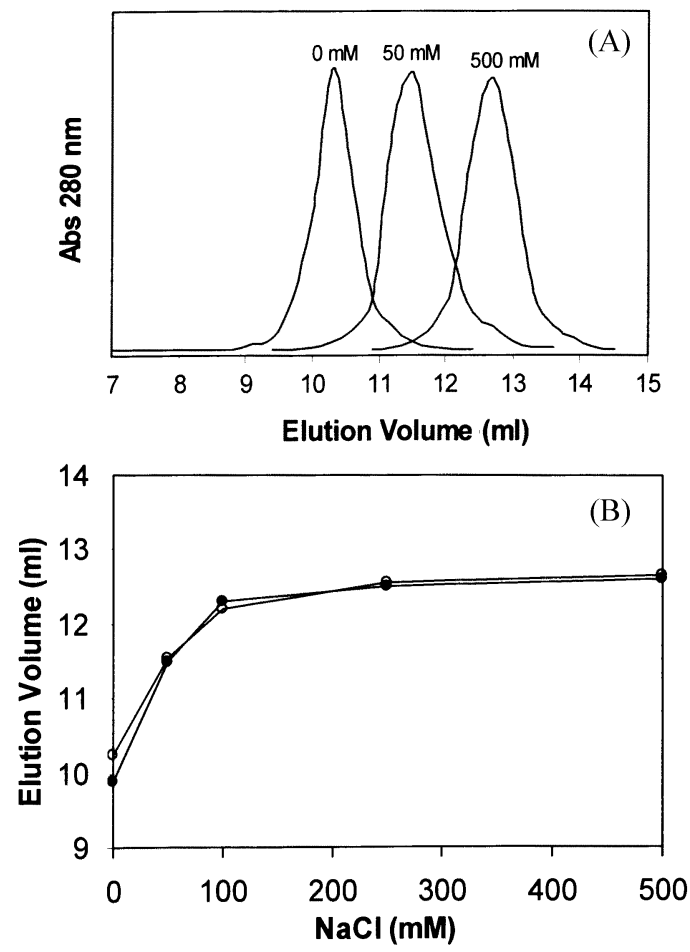

Fig. 6. Gel filtration chromatography. (A) The elution profile of the enzyme in the presence of $0 \mathrm{mM}, 50 \mathrm{mM}$, and $500 \mathrm{mM}$ of $\mathrm{NaCl}$. (B) The dependence of the elution volume on the $\mathrm{NaCl}$ concentration in the presence of $50 \mathrm{mM}$ D-alanine ( $)$ and in the absence of the substrate $(\bigcirc)$.

reported the effects of salts on PLP-dependent enzymes. For example, the tryptophan synthase $\alpha_{2} \beta_{2}$ complex is activated by both $\mathrm{NaCl}$ and $\mathrm{CsCl}$ in the $\beta$-replacement reaction (Peracchi et al., 1995), but the $\beta$ subunit alone is inhibited by $\mathrm{NaCl}$ and stimulated by $\mathrm{CsCl}$ (H. S. Ro and E. W. Miles, unpublished results). Tyrosine phenol-lyase and tryptophan indole-lyase are activated by $\mathrm{K}^{+}$and $\mathrm{NH}_{4}{ }^{+}$ions (Demidkina and Miagkikh, 1989). Dialkylglycine decarboxylase is inhibited by $\mathrm{Na}^{+}$and activated by $\mathrm{K}^{+}$(Toney et al., 1993; Hohenester et al., 1994). $\mathrm{CsCl}$ activates Ornithine decarboxylase (Lee et al., 2001). For these enzymes, monovalent cations bind to the specific sites and affect both conformation and catalysis (Hyde et al., 1988; Toney et al., 1993; Rhee et al., 1996; Isupov et al., 1998). Therefore, the effects that are seen with these enzymes are clearly different from the effects of salt on D-AAT. An activity vs. salt concentration profile demonstrates that D-AAT activity is significantly inhibited by the high salt concentration. This is consistent with previous finding (van Opem et al., 1998). The salts of higher ionic strength, $\mathrm{CaCl}_{2}$, $\mathrm{Na}_{2} \mathrm{SO}_{4}$ (this work), and $\mathrm{MgCl}_{2}$ (van Opem et al., 1998), inhibited at lower concentrations than those of the lower ionic strength.

Salts decrease the accumulation of E-Q The accumulation of E-Q in the reaction of D-AAT with D-serine decreased with the increase of $\mathrm{NaCl}$ or $\mathrm{CaCl}_{2}$ concentrations (Fig. 3BC). The crystal structure of aspartate aminotransferase with erythro- $\beta$ hydroxy-L-aspartate revealed that a hydrogen bond network between the $\beta$-hydroxyl group of substrate and the enzyme groups (Tyr70, Lys258) stabilizes E-Q (absorbs at $493 \mathrm{~nm}$ ) and E-carbinolamine (absorbs at $330 \mathrm{~nm}$ ). It may be responsible for the accumulation of E-Q and E-carbinolamine (Hayashi and Kagamiyama, 1995; von Stosch, 1996). A similar study was done with aromatic amino acid aminotransferase (Hayashi et al., 1996). It is, therefore, crucial for the enzyme to have a correct arrangement of the active site groups in order to accumulate E-Q. Although the stereospecificity of D-AAT is opposite to that of aspartate aminotransferase, crystallographic data revealed that the arrangement of the active site groups is quite similar (Sugio et al., 1995). The fact that the reaction of D-AAT with D-serine and erythro- $\beta$-hydroxy-DL-aspartate results in the accumulation of E-Q as a major peak, but the reaction of Dthreonine that has a threo $\beta$-hydroxy group could not, suggests the requirement of a certain structural arrangement of the active site groups for the accumulation of E-Q (Martinez del Pozo et al., 1989). Therefore, the inhibitory salt effect on the accumulation may be caused by a salt-induced enzyme conformational change that disturbs the hydrogen bond network in the active site that stabilizes E-Q. The destabilizing effects of salt on E-Q influences not only the accumulation, but also the rate of formation (Fig. 4). The protective effect of salt from the substrate-induced inactivation may simply reflect the reduced rate of the E-Q formation since the inactivation is proportional to the formation of E-Q.

$\mathrm{NaCl}$ decreases the deprotonation rate at a-carbon The results of the $\mathrm{NaCl}$ effect on the reaction of D-AAT with $\alpha$ $\left[{ }^{2} \mathrm{H}\right]$-DL-serine indicate that $\mathrm{NaCl}$ decreases the rate of formation of E-Q (Fig. 5). Since the formation of E-Q requires the deprotonation at the $\alpha$-carbon of the substrate, the rate decrease in the E-Q formation is related to the decrease of the ability of the enzyme groups that are responsible for the deprotonation.

$\mathrm{NaCl}$ significantly reduces the enzyme volume From the gel filtration study, it is obvious that the presence of $\mathrm{NaCl}$ significantly increases the elution volume, which indicates the salt-dependent reduction of the enzyme volume (Fig. 6). The lack of change in the elution volume above $100 \mathrm{mM}$ of $\mathrm{NaCl}$ indicates that the enzyme has a limited number of surface groups. Replacement of these surface groups from water to salt may decrease the total enzyme volume. Low and Somero (1975a, b) reported that the presence of salt disrupts the dense hydration spheres around the exposed protein groups, which leads to either an increase or decrease of the enzyme volume. The paper suggested that the enzyme requires a certain amount of activation volume, which is the volume difference in the enzyme substrate complex between the transition and ground states. Therefore, the constriction of the enzyme that is 
induced by salt may not provide the required activation volume, resulting in the inhibition of the enzyme activity.

The studies demonstrate that the binding of salt to the groups in D-AAT reduces the enzyme volume significantly. This may disturb the arrangement of the active site groups that are responsible for the stabilization of E-Q and deprotonation at the $\alpha$-carbon of the substrate. The effects of salt on protection from the inactivation (van Opem et al., 1998) and inhibition of the activity (this study and van Opem et al., 1998) are a consequence of the salt-induced enzyme volume reduction.

Acknowledgments I am grateful to Drs. Moon-Hee Sung (KRIBB), Hak-Sung Kim (KAIST), and Edith W. Miles (NIH) for their critical comments on this manuscript.

\section{References}

Bhatia, M. B., Martinez del Pozo, A., Ringe, D., Yoshimura, T., Soda, K. and Manning, J. M. (1993) Role reversal for substrates and inhibitors. Slow inactivation of D-amino acid transaminase by its normal substrates and protection by inhibitors. J. Biol. Chem. 268, 17687-17694.

Demidkina, T. V. and Myagkikh, I. V. (1989) The activity and reaction specificity of tyrosine phenol-lyase regulated by monovalent cations. Biochimie 71, 565-571.

Fotheringham, I. G., Bledig, S. A. and Taylor, P. P. (1998) Characterization of the genes encoding D-amino acid transaminase and glutamate racemase, two D-glutamate biosynthetic enzymes of Bacillus sphaericus ATCC 10208. J. Bacteriol. 180, 4319-4323.

Hayashi, H. and Kagamiyama, H. (1995) Reaction of aspartate aminotransferase with L-erythro-3-hydroxyaspartate: involvement of Tyr70 in stabilization of the catalytic intermediates. Biochemistry 34, 9413-9423.

Hayashi, H., Inoue, K., Mizuguchi, H. and Kagamiyama, H. (1996) Analysis of the substrate-recognition mode of aromatic amino acid aminotransferase by combined use of quasisubstrates and site-directed mutagenesis: systematic hydroxy-group addition/deletion studies to probe the enzymesubstrate interactions. Biochemistry 35, 6754-6761.

Hohenester, E., Keller, J. W. and Jansonius, J. N. (1994) An alkali metal ion size-dependent switch in the active site structure of dialkylglycine decarboxylase. Biochemistry 33, 13561-13570.

Hyde, C. C., Ahmed, S. A., Padlan, E. A., Miles, E. W. and Davies, D. R. (1988) Three-dimensional structure of the tryptophan synthase $\alpha_{2} \beta_{2}$ multienzyme complex from Salmonella typhimurium. J. Biol. Chem. 263, 17857-17871.

Isupov, M. N., Antson, A. A., Dodson, E. J., Dodson, G. G., Dementieva, I. S., Zakomirdina, L. N., Wilson, K. S., Dauter, Z., Lebedev, A. A. and Harutyunyan, E. H. (1998) Crystal structure of tryptophanase. J. Mol. Biol. 276, 603-623.

Kim, S. S. and Yu, Y. G. (2000) Molecular cloning of an extremely thermostable alanine racemase from Aquifex pyrophilus and enzymatic characterization of the expressed protein. J. Biochem. Mol. Biol. 33, 82-88.

Lee, Y. S., Lee, G. T. and Cho, Y. D. (2001) Regulation of Glyine $\max$ ornithine decarboxylase by salt and spermine. J. Biochem.
Mol. Biol. 34, 478-483.

Low, P. S. and Somero, G. N. (1975a) Activation volumes in enzymatic catalysis: their sources and modification by lowmolecular-weight solutes. Proc. Natl. Acad. Sci. USA 72, 30143018.

Low, P. S. and Somero, G. N. (1975b) Protein hydration changes during catalysis: a new mechanism of enzymatic rateenhancement and ion activation/inhibition of catalysis. Proc. Natl. Acad. Sci. USA 72, 3305-3309.

Martinez del Pozo, A., Pospischil, M. A., Ueno, H., Manning, J. M., Tanizawa, K., Nishimura, K., Soda, K., Ringe, D., Stoddard, B. and Petsko, G. (1989) Effects of D-serine on bacterial D-amino acid transaminase: accumulation of an intermediate and inactivation of the enzyme. Biochemistry 28, 8798-8803.

Martinez del Pozo, A., Yoshimura, T., Bhatia, M. B., Futaki, S., Manning, J. M., Ringe, D. and Soda, K. (1992) Inactivation of dimeric D-amino acid transaminase by a normal substrate through formation of an unproductive coenzyme adduct in one subunit. Biochemistry 31, 6018-6023.

Martinez-Carrion, M. and Jenkins, W. T. (1965a) D-Alanine-Dglutamate transaminase. I. Purification and characterization. $J$. Biol. Chem. 240, 3538-3546.

Martinez-Carrion, M. and Jenkins, W. T. (1965b) D-Alanine-Dglutamate transaminase. II. Inhibitors and the mechanism of transamination of D-amino acids. J. Biol. Chem. 240, 35473552.

Miles, E. W. and McPhie, P. (1974) Evidence for a ratedetermining proton abstraction in the serine deaminase reaction of the beta 2 subunit of tryptophan synthetase. J. Biol. Chem. 249, 2852-2857.

Peracchi, A., Mozzarelli, A. and Rossi, G. L. (1995) Monovalent cations affect dynamic and functional properties of the tryptophan synthase $\alpha_{2} \beta_{2}$ complex. Biochemistry 34, 94599465.

Rhee, S., Parris, K. D., Ahmed, S. A., Miles, E. W. and Davies, D. R. (1996) Exchange of $\mathrm{K}+$ or $\mathrm{Cs}+$ for $\mathrm{Na}+$ induces local and long-range changes in the three-dimensional structure of the tryptophan synthase $\alpha_{2} \beta_{2}$ complex. Biochemistry 35, 42114221.

Ro, H. S., Hong, S. P., Seo, H. J., Yoshimura, T., Esaki, N., Soda, K., Kim, H. S. and Sung, M. H. (1996) Site-directed mutagenesis of the amino acid residues in beta-strand III [Val30-Val36] of D-amino acid aminotransferase of Bacillus sp. YM-1. FEBS Lett. 398, 141-145.

Soper, T. S. and Manning, J. M. (1981) Different modes of action of inhibitors of bacterial D-amino acid transaminase. A target enzyme for the design of new antibacterial agents. J. Biol. Chem. 256, 4263-4268.

Suelter, C. H. and Snell, E. E. (1977) Monovalent cation activation of tryptophanase. J. Biol. Chem. 252, 1852-1857.

Sugio, S., Petsko, G. A., Manning, J. M., Soda, K. and Ringe, D. (1995) Crystal structure of a D-amino acid aminotransferase: How the protein controls stereoselectivity. Biochemistry 34, 9661-9669.

Tanizawa, K., Masu, Y., Asano, S., Tanaka, H. and Soda, K. (1989) Thermostable D-amino acid aminotransferase from a thermophilic Bacillus species. Purification, characterization, and active site sequence determination. J. Biol. Chem. 264, 24452449. 
Toney, M. D., Hohenester, E., Cowan, S. W. and Jansonius, J. N. (1993) Dialkylglycine decarboxylase structure: Bifunctional active site and alkali metal sites. Science 261, 756-759.

van Ophem, P. W., Erickson, S. D., Martinez del Pozo, A., Haller, I., Chait, B. T., Yoshimura, T., Soda, K., Ringe, D., Petsko, G. and Manning, J. M. (1998) Substrate inhibition of D-amino acid transaminase and protection by salts and by reduced nicotinamide adenine dinucleotide: isolation and initial characterization of a pyridoxo intermediate related to inactivation. Biochemistry 37, 2879-2888.

von Stosch, A. G. (1996) Aspartate aminotransferase complexed with erythro-beta-hydroxyaspartate: crystallographic and spectroscopic identification of the carbinolamine intermediate. Biochemistry 35, 15260-15268.

Yonaha, K., Misono, H., Yamamoto, T. and Soda, K. (1975) Damino acid aminotransferase of Bacillus sphaericus. Enzymologic and spectrometric properties. J Biol. Chem. 250, 6983-6989. 